\title{
Effect of IBA, rooting media and planting date on vegetative propagation of button wood tree (Conocarpus erectus $L$.)
}

\author{
Safaa, M. Mohamed, Youssef, A. S. M. and N. E. Hegazy \\ Horticulture, Dept., Fac. of Agric., Benha University.
}

\begin{abstract}
This work was carried out during the two successive seasons of 2010/2011 and 2011/2012at the Experimental Lathe House of Horticulture Dept., Faculty of Agric., Benha University, Kalubia Governorate, Egypt, to study the effect of IBA, rooting media and planting date as well as their combinations on rooting percentage, root number and fresh and dry weights of roots as well as root anatomical features of Conocarpus erectus L cuttings. The recorded data showed that: all tested concentrations of IBA statistically increased rooting percentage of conocarpus as compared with untreated cuttings in both seasons. However, the highest value of rooting percentage was gained by $3000 \mathrm{ppm}$ IBA- treated cuttings. Using $\mathrm{M}_{4}$ ( sand + clay + peat moss + perlite) showed to be the most effective one for inducing the highest rooting percentage, followed in a descending order by $\mathrm{M}_{2}$ ( sand + clay + peat moss ) in both seasons . Rooted conocarpus cuttings in July month significantly produced the highest values of rooting percentage, followed in a descending order by May then September months in both seasons. The combinations of July month statistically induced the highest values of rooting percentage, especially those received IBA at $3000 \mathrm{ppm}$ and rooted in $\mathrm{M}_{4}$ medium. IBA at either 2000 or $3000 \mathrm{ppm}$ increased the root number of cuttings, with superiority of $2000 \mathrm{ppm}$ as compared with untreated cuttings at both seasons. Using $\mathrm{M}_{4}$ proved to be the most effective one for producing the highest number of roots/ cutting as well as their fresh and dry weights, followed by using $\mathrm{M}_{3}$ in both seasons. Planting cuttings in May month induced the highest number of roots /cutting as well as their fresh and dry weights, followed in a descending order by July and March months in both seasons. The combination of May month registered the highest values of these parameters, especially those treated with IBA at either 2000 or $3000 \mathrm{ppm}$ and rooted in $\mathrm{M}_{4}$ medium. Moreover, most of the tested treatments affected the root anatomical features of conocarpus plants.
\end{abstract}

Key words: Conocarpus erectus, vegetative propagation, cuttings, rooting percentage and root anatomical features.

\section{Introduction}

The genus Conocarpus is composed of two species native of North America and shores of tropical America and Africa. The word Conocarpus means "conefruit", in reference to the cone like round fruits ( Elias, 1980).

Conocarpus erectus L. (botton wood, sea mulberry, botton mangrove, green botton wood, gray mangrove, button bush) belongs to the Family Combretaceae. Conocarpus erectus.. Botton wood plant is alow- branching, multi-trunked, shrubby and evergreen tree. Leaves are evergreen, alternate, thick and leathery, with an entire margin, generally oval but variable to 4 inches long and 2 inches wide, green and glabrous above and below. The root system consists mainly of laterals and fine roots that are dark brown, weak and brittle and have a corky bark. The bark is gray or brown, furrowed, fibrous and moderately thin (about $8 \mathrm{~mm}$ ). The inner bark is dark cream in colour. Stem wood is hard, heavy and strong. Branches and brittle twigs are slender, yellow-green, angled, flattened, or winged. (Lilte and Wadswerth 1964; Pennington and Sarukhan 1968; Howard 1989; Liogier 1994; Nelson 1996 and Stevens et al. 2001).

Botton wood is highly tolerant to full sun, sandy soil, salty conditions, air pollution, poor drainage, and drought. Botton wood is used also as an ornamental tree or shrub and in bonsai. Botton wood trees are tough and long- lasting in the landscape. It is used for seaside planting, as a hedge; shade tree, residential street tree, buffer strips around parking lots, specimen, side walk cutout ( tree pit), median strip planting in the high way; ...... etc (Gilman and Watson, 1993).

Vegetative Propagation is used in the horticultural nursery industry to mass- produce selected superior plants genotypes as cultivars (Hartmann et al., 1997). The seasons of propagation during which the cuttings are taken varies from one species to another and has a great effect on rooting. In this respect, Abou Dahab et al. (1975) reported that the best time for planting cuttings of Myrtus communis was from November to December, while Istas and Meneve (1980) found that the best time for taking cuttings of Magnolia seibodii is mid-may .Also, many authors studied the effect of planting media on rooting of cuttings, in this concern ElGendy et al. (1995a) using a mixture of sand + peat as a growing medium obtained improved rooting percentage of Pilea and Hedera plants., Abo- Hassan et al. (1994) found that the best rooting percentage of Ficus infectoria cuttings was obtained by using perlite + peat moss medium. Many experiments have been done in order to study the effect of growth substances on rooting percentage of stem cuttings. In this sphere, El- Boraie (1998) found that IBA at 
$4000 \mathrm{ppm}$ gave the highest rooting percentage of terminal and sub terminal cuttings of Jasminum sambac. Root length, number and dry weight of roots increased with IBA treatments as compared with control. This study aimed to evaluate the feasibility of button wood cuttings to produce rooted seedlings.

\section{Materials and methods}

This study was carried out during 2010/2011 and 2011/2012 seasons at the nursery of Horticulture .Dept, Faculty of Agric., Benha Univ., Qalubia Governorate to study the effect of some different rooting media and IBA concentrations under different planting dates.

- Plant material : Soft wood cuttings of Concarpus erectus $\mathrm{L}$. were used, the cuttings were collected on Jannuary, March, May, July, September and November for each season from certain mother trees of three years old trees, the cuttings were $7.8 \mathrm{~cm}$ long and about $2 \mathrm{~mm}$ diameter. The leaves of the cuttings were shortened, then the cuttings were disinfected with Rhizolex fungicide powder at $0.3 \%$ concentration, and were treated with the following IBA concentrations:

1- IBA at $0.0 \mathrm{mg} / 1$ (control) 2- IBA at $2000 \mathrm{mg} / \mathrm{l} \mathrm{3-}$ IBA at $3000 \mathrm{mg} / \mathrm{l}$.

Each cutting was inserted in a $5 \mathrm{~cm}$ diameter plastic pot containing different rooting media as follows:

1- Sand + clay ( v:v) 2- Sand + clay + peatmoss (v:v) 3-Sand + clay + pelite (v:v)

4- Sand + clay + peatmoss + perlite $(\mathrm{v}: \mathrm{v})$

Each treatment was represented by three replicates and each replicate included 10 cuttings. All inserted cuttings were held in the greenhouse under tunnels and 60 days later the following data were recorded

A- Rooting percentage and number of roots /cuttings as well as their fresh and dry weights.

\section{B-Anatomical study:}

The samples of root were taken in May month and the samples were taken from all treatments including the control. The specimens were taken then killed and fixed in FAA ( $5 \mathrm{ml}$. formalin, $5 \mathrm{ml}$. glacial acetic acid and 90ml. ethyl alchohol 70\%), washed in $50 \%$ ethyl alcohol, dehydrated in series of ethyl alchohol of 70,90,95 and 100\%, infiltrated in xylene, embedded in paraffin wax with a melting point of 6063C, sectioned to 20 microns in thickness (Sass, 1951), stained with the double stain method (fast green and safranin), cleared in xylene and mounted in Canada balsam (Johanson, 1940). Sections were read to detect histological manifestation of noticeable responses resulted from other treatments. The prepared section were microscopically examined, counts and measurements $(\mu)$ were taken using a micrometer eye piece.

\section{Statistical analysis}

The obtained data were statistically analyzed using randomized complete split - split block design according to Snedecor and Cochran (1989), planting dates occupied the main plot, the subplots were devoted for rooting media, while the sub subplots were employed for IBA concentrations. Means were compared using L.S.D test at $5 \%$ level

\section{Results and Discussion}

Effect of IBA, rooting media and planting date as well as their combinations on rooting percentage, root number as well as their fresh and dry weights/cutting and root anatomical features of Conocorpus erectus plants:

\section{1- Rooting percentage}

Data presented in Table (1) reveal that all tested concentrations of IBA statistically increased rooting percentage of conocarpus as compared with untreated cuttings in both seasons. However, the highest value of rooting percentage was gained by $3000 \mathrm{mg} / \mathrm{l}$ IBA- treated cuttings as it gave 58.76 and $57.71 \%$, followed by $2000 \mathrm{mg} / \mathrm{l} \mathrm{IAB}$ - treated cuttings which scored 51.81 and $52.00 \%$ in the first and second seasons, respectively.

As for the effect of rooting media, data in the same Table show that using $\mathrm{M}_{4}$ ( sand + clay + peatmoss + perlite) showed to be the most effective one for inducing the highest rooting percentage , followed in adescending order by $\mathrm{M}_{2}$ ( sand + clay + peat moss ) in both seasons. On contrary, the lowest rooting percentage was recorded in by using $\mathrm{M}_{1}$ (sand + clay), followed in ascending order by $\mathrm{M}_{3}$ (sand + clay + perlite). This trend was true in both seasons of this study.

Considering the effect of planting date, data presented in Table (1) demonstrate that rooted conocarpus cuttings in July month significantly produced the highest values of rooting percentage as it gave 80.506 and $86.725 \%$, followed in adescending order by May then September months in both seasons. On the reverse, the least rooting percentage was recorded in January month, followed in ascending order by November and March months. This trend was true in both seasons.

Regarding the interaction effect between IBA concentrations, rooting media and rooting dates, data presented in Table (1) declare that the combinations of July month statistically induced the highest values of rooting percentage; especially those received IBA at $3000 \mathrm{mg} / \mathrm{l}$ and rooted in $\mathbf{M}_{4}$ medium as it gave 96.30 and $98.667 \%$ in the first and second seasons, respectively. Also, the cuttings which received IBA at $3000 \mathrm{mg} / \mathrm{l}$ and rooted in $\mathbf{M}_{2}$ in July month gave high increments in this parameter as it registered 94.533 and $96.667 \%$, in the first and second seasons, respectively. On the opposite, the combination of January month statistically scored the lowest values of rooting percentage, particularly those rooted in $\mathrm{M}_{1}$ and received no IBA treatments in both seasons. The remained treatments occupied an intermediate 
position between the aforementioned treatments in both seasons.

The aforementioned results of IBA treatments are in parallel with those obtained by Helaly (2009) on Concarpus. erectus, Blithe (1990) on Cupressus glabra, sundaram, ouriculata, Teklehaimanot et al (1996) on Porkia biglobosa, El- Boraie (1998) on Jasminum sambac .

The results of rooting media coincide with those obtained by Helaly (2009) on Concarpus. erectus , Siraj- Ali and Abou- Dahab (1993) on Ficus benjamina, Abo- Hassan et al (1994) on Ficus infectoria, El- Gendy et al (1995a) on Pillea and Hedera plant .

In addition the results of cutting date go on line with those obtained by Helaly (2009) on Concarpus. erectus, Istas and Meneve (1980) on Magnolia seibodii, Popovic (1984) on Actinidia chinensis, Shen and Chen (1990) on Lcycim barbarum L., Sawwan (1993) on Gypsophila panicullata, Singh (1993) on Bougainvillea plants .

Table 1. Effect of IBA, rooting media and planting date as well as their combination on rooting percentage of Conocarpus erectus during the two successive seasons of 2010/2011 and 20112012.

\begin{tabular}{|c|c|c|c|c|c|c|c|c|}
\hline \multicolumn{2}{|c|}{ Months } & \multirow{2}{*}{ Jan } & \multirow{2}{*}{ Mar } & \multirow{2}{*}{. May } & \multirow{2}{*}{. July } & \multirow{2}{*}{ Sep. } & \multirow{2}{*}{ Nov. } & \multirow{2}{*}{ Mean } \\
\hline IBA(mg/l) & Media & & & & & & & \\
\hline \multirow{4}{*}{$\stackrel{0}{0}$} & $\mathrm{M}_{1}$ & 8.333 & 25.133 & 45.233 & 63.400 & 38.300 & 14.633 & \multirow[t]{4}{*}{36.47} \\
\hline & $\mathrm{M}_{2}$ & 11.267 & 24.800 & 49.367 & 71.700 & 47.500 & 18.500 & \\
\hline & $\mathrm{M}_{3}$ & 9.400 & 23.533 & 47.467 & 68.433 & 44.884 & 21.400 & \\
\hline & $\mathrm{M}_{4}$ & 12.367 & 28.700 & 52.533 & 74.633 & 49.233 & 24.567 & \\
\hline \multirow{4}{*}{$\underset{8}{8}$} & $\mathrm{M}_{1}$ & 11.733 & 31.700 & 68.300 & 78.333 & 53.933 & 27.800 & \multirow[t]{4}{*}{51.81} \\
\hline & $\mathrm{M}_{2}$ & 12.533 & 36.633 & 84.800 & 88.433 & 69.233 & 2.833 & \\
\hline & $\mathrm{M}_{3}$ & 13.367 & 34.833 & 76.400 & 83.567 & 67.133 & 29.567 & \\
\hline & $\mathrm{M}_{4}$ & 14.433 & 39.467 & 87.467 & 91.600 & 74.467 & 34.933 & \\
\hline \multirow{4}{*}{ ষ্ণ } & $\mathrm{M}_{1}$ & 14.200 & 38.633 & 74.600 & 62.333 & 70.333 & 36.467 & \multirow[t]{4}{*}{58.76} \\
\hline & $\mathrm{M}_{2}$ & 16.200 & 46.467 & 92.600 & 94.533 & 79.400 & 39.500 & \\
\hline & $\mathrm{M}_{3}$ & 15.367 & 42.533 & 90.400 & 92.800 & 77.567 & 41.467 & \\
\hline & $\mathrm{M}_{4}$ & 17.867 & 49.433 & 94.800 & 96.300 & 83.567 & 42.867 & \\
\hline \multicolumn{2}{|c|}{ Mean } & 13.089 & 35.156 & 71.997 & 80.506 & 62.963 & 30.378 & \\
\hline \multicolumn{2}{|c|}{ Means of media } & $\mathrm{M}_{1}=42.410$ & $\mathrm{M}_{2}=50.910$ & \multicolumn{2}{|c|}{$\mathrm{M}_{3}=48.890$} & \multicolumn{2}{|c|}{$\mathrm{M}_{4}=53.850$} & \\
\hline \multicolumn{2}{|c|}{ LSD at $5 \%$} & $\mathrm{IBA}=4.132$ & media $=4$ & 958 & months $=6$. & $46 \quad$ inters & tion $=9.668$ & \\
\hline \multicolumn{9}{|c|}{ Second Season } \\
\hline \multirow{4}{*}{$\stackrel{0}{0}$} & $\mathrm{M}_{1}$ & 6.280 & 26.500 & 52.400 & 66.167 & 43.933 & 9.427 & \multirow[t]{4}{*}{38.97} \\
\hline & $\mathrm{M}_{2}$ & 9.477 & 29.467 & 4.833 & 76.300 & 58.533 & 12.567 & \\
\hline & $\mathrm{M}_{3}$ & 8.267 & 28.467 & 63.500 & 73.500 & 49.467 & 11.410 & \\
\hline & $\mathrm{M}_{4}$ & 9.767 & 29.767 & 69.467 & 78.533 & 52.567 & 14.667 & \\
\hline \multirow{4}{*}{ 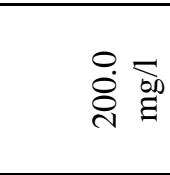 } & $\mathrm{M}_{1}$ & 8.733 & 29.400 & 73.867 & 82.600 & 69.533 & 12.367 & \multirow[t]{4}{*}{52.00} \\
\hline & $\mathrm{M}_{2}$ & 11.300 & 34.533 & 84.467 & 96.167 & 82.767 & 14.467 & \\
\hline & $\mathrm{M}_{3}$ & 9.800 & 32.700 & 79.600 & 91.367 & 81.400 & 15.867 & \\
\hline & $\mathrm{M}_{4}$ & 12.433 & 36.467 & 87.133 & 98.433 & 84.667 & 18.133 & \\
\hline \multirow{4}{*}{ ஓ్ర } & $\mathrm{M}_{1}$ & 11.363 & 39.467 & 81.633 & 85.400 & 74.467 & 18.367 & \multirow[t]{5}{*}{$\overline{57.71}$} \\
\hline & $\mathrm{M}_{2}$ & 13.500 & 46.433 & 89.500 & 96.667 & 86.633 & 25.700 & \\
\hline & $\mathrm{M}_{3}$ & 14.233 & 44.533 & 84.767 & 93.300 & 82.700 & 23.700 & \\
\hline & $\mathrm{M}_{4}$ & 15.300 & 47.700 & 93.600 & 98.667 & 88.133 & 29.333 & \\
\hline \multicolumn{2}{|c|}{ Mean } & 10.871 & 35.453 & 77.064 & 86.425 & 70.400 & 17.167 & \\
\hline \multicolumn{2}{|c|}{ Means of media } & $\mathrm{M}_{1}=43.990$ & $\mathrm{M}_{2}=51$. & 290 & $\mathrm{M}_{3}=49.360$ & & $\mathrm{M}_{4}=53.600$ & \\
\hline LSD & & $\mathrm{IBA}=3.2$ & Media $=3$ & .941 & Months $=5$. & Inter & tion $=7.684$ & \\
\hline
\end{tabular}

$\mathbf{M}_{1}=$ Sand + clay, $\mathbf{M}_{2}=$ Sand + clay + peatmoss, $\mathbf{M}_{3}=$ Sand + clay + perlite, $\mathbf{M}_{4}=$ Sand + clay + peatmoss + perlite

\section{2- Root number}

Data presented in Table (2) clear that IBA at either 2000 or $3000 \mathrm{mg} / \mathrm{l}$ increased the root number of Conocarpus erectus cuttings, with superiority for IBA in $2000 \mathrm{mg} / \mathrm{l}$ as compared with untreated cuttings at both seasons. The differences between the two used IBA concentrations were non-significant in both seasons. Regarding the effect of rooting media, data refer that using $\mathrm{M}_{4}$ approved to be the most effective one for producing the highest number of roots/ cutting, followed by using $\mathrm{M}_{3}$ in both seasons. On contrary, $\mathrm{M}_{1}$ medium recorded the lowest number of roots /cutting is both seasons. As for the effect of planting date, data in show that planting conocarpus cuttings in May month induced the highest number of roots /cuttings, followed in adescending order by July then March months in both seasons. On the reverse, the lowest number of roots / cuttings were 
scored in January and November months in both seasons.

Considering the interaction effect between IBA, rooting media and planting date, data presented in Table (2) indicate that the combination of May month registered the highest values of this parameter, especially those treated with IBA at $2000 \mathrm{mg} / \mathrm{l}$ and rooted in $\mathrm{M}_{4}$ medium, whereas the combination of January and November months gave the lowest values in this concern, particularly those received no IBA treatments in both seasons. The rest treatments came in between in both seasons. These results are in agreement with those obtained by Bhattacharjee and Thimmapaa (1991) on Pelargonium graveolens who mentioned that the best results (100\% rooting, 28.3 roots/ cutting and a longest root length of 19.3 $\mathrm{cm})$ were obtained from treating with IBA at 2000 $\mathrm{mg} / \mathrm{l}$, Eltorky and Shennawy, (1993b) found that the cutting of cultivars of Ficus deltoidea and Euphorbia pulcherrima cuttings were treated with various concentrations of IBA. Generally root length was significantly increased due to IBA, Panwar et al., (1994) reported that IBA at $2000 \mathrm{mg} / \mathrm{l}$ was the best treatment for increasing rooting percentage of Bougairvillea cuttings.

Table 2. Effect of IBA, rooting media and planting date as well as their combination on root number of Conocarpus erectus during the two successive seasons of 2010/2011 and 20112012.

\begin{tabular}{|c|c|c|c|c|c|c|c|c|}
\hline \multicolumn{2}{|l|}{ Months } & \multirow{2}{*}{ Jan } & \multirow{2}{*}{ Mar. } & \multirow{2}{*}{ May } & \multirow{2}{*}{ July } & \multirow{2}{*}{ Sept. } & \multirow{2}{*}{ Nov. } & \multirow{2}{*}{ Mean } \\
\hline IBA $(\mathrm{mg} / \mathrm{l})$ & Media & & & & & & & \\
\hline \multirow{4}{*}{$\stackrel{0}{0}$} & $\mathrm{M}_{1}$ & 8.133 & 10.433 & 12.500 & 12.400 & 11.45 & 9.333 & \multirow{4}{*}{11.597} \\
\hline & $\mathrm{M}_{2}$ & 8.833 & 11.333 & 3.600 & 13.233 & 11.567 & 10.300 & \\
\hline & $\mathrm{M}_{3}$ & 9.267 & 11.167 & 14.267 & 14.067 & 11.733 & 9.8 & \\
\hline & $\mathrm{M}_{4}$ & 9.667 & 12.833 & 14.933 & 14.367 & 12.400 & 0.700 & \\
\hline \multirow{4}{*}{ §্ণ } & $\mathrm{M}_{1}$ & 11.233 & 13.400 & 13.933 & 13.600 & 12.767 & 10.233 & \multirow{4}{*}{13.781} \\
\hline & $\mathrm{M}_{2}$ & 13.667 & 14.267 & 14.933 & 14.433 & 13.900 & 11.300 & \\
\hline & $\mathrm{M}_{3}$ & 14.167 & 14.933 & 15.633 & 15.300 & 14.233 & 11.933 & \\
\hline & $\mathrm{M}_{4}$ & 14.933 & 15.333 & 16.233 & 15.867 & 14.533 & 12.367 & \\
\hline \multirow{4}{*}{ ঠ్రి } & $\mathrm{M}_{1}$ & 10.667 & 12.433 & 13.367 & 13.305 & 11.767 & 9.967 & \multirow{5}{*}{13.170} \\
\hline & $\mathrm{M}_{2}$ & 11.867 & 13.233 & 14.233 & 14.333 & 12.667 & 11.333 & \\
\hline & $\mathrm{M}_{3}$ & 12.367 & 14.600 & 15.500 & 15.233 & 13.800 & 11.267 & \\
\hline & $\mathrm{M}_{4}$ & 13.100 & 14.867 & 15.733 & 15.467 & 13.867 & 11.100 & \\
\hline Mean & & 11.492 & 13.236 & 14.572 & 14.300 & 12.892 & 10.803 & \\
\hline Means of media & \multicolumn{2}{|c|}{$\mathrm{M}_{1}=11.719 \quad \mathrm{M}_{2}=$} & 2.72 & \multicolumn{2}{|c|}{$\mathrm{M}_{3}=13.293$} & \multicolumn{2}{|c|}{$\mathrm{M}_{4}=13.794$} & \\
\hline LSD at $5 \%$ & $\mathrm{IBA}=$ & 140 & $\mathrm{dia}=1.368$ & mon & $\mathrm{s}=1.778$ & action $=2$. & & \\
\hline \multicolumn{9}{|c|}{$\begin{array}{c}\text { Second Season } \\
\end{array}$} \\
\hline \multirow{4}{*}{$\stackrel{0}{0}$} & $\mathrm{M}_{1}$ & 7.800 & 9.800 & 12.867 & 12.733 & 9.633 & 8.433 & \multirow{4}{*}{11.199} \\
\hline & $\mathrm{M}_{2}$ & 9.433 & 10.333 & 13.433 & 13.133 & 10.233 & 9.100 & \\
\hline & $\mathrm{M}_{3}$ & 9.167 & 11.167 & 14.633 & 14.167 & 10.167 & 9.733 & \\
\hline & $\mathrm{M}_{4}$ & 9.533 & 12.433 & 14.900 & 14.433 & 11.267 & 10.233 & \\
\hline \multirow{4}{*}{ ঠి } & $\mathrm{M}_{1}$ & 10.900 & 12.833 & 13.433 & 12.833 & 12.533 & 11.333 & \multirow{4}{*}{13.785} \\
\hline & $\mathrm{M}_{2}$ & 12.167 & 14.533 & 14.267 & 13.867 & 13.000 & 12.533 & \\
\hline & $\mathrm{M}_{3}$ & 13.967 & 14.367 & 15.933 & 15.467 & 13.633 & 12.933 & \\
\hline & $\mathrm{M}_{4}$ & 14.367 & 15.033 & 16.633 & 15.833 & 14.000 & 14.433 & \\
\hline \multirow{4}{*}{ ঠ্ণ } & $\mathrm{M}_{1}$ & 10.533 & 12.600 & 13.567 & 12.467 & 12.133 & 11.333 & \multirow{5}{*}{13.200} \\
\hline & $\mathrm{M}_{2}$ & 11.833 & 13.467 & 14.000 & 12.800 & 12.833 & 12.667 & \\
\hline & $\mathrm{M}_{3}$ & 12.900 & 13.767 & 14.767 & 14.600 & 13.433 & 13.233 & \\
\hline & $\mathrm{M}_{4}$ & 13.133 & 14.433 & 15.438 & 14.232 & 13.533 & 13.100 & \\
\hline \multicolumn{2}{|l|}{ Mean } & 11.311 & 12.897 & 14.489 & 13.881 & 12.200 & 11.589 & \\
\hline \multicolumn{2}{|c|}{ Means of media } & $\mathrm{M}_{1}=11.543$ & \multicolumn{2}{|c|}{$\mathrm{M}_{2}=12.424$} & $\mathrm{M}_{3}=48.890$ & \multicolumn{2}{|c|}{$\mathrm{M}_{4}=13.721$} & \\
\hline LSD at $5 c$ & & $\mathrm{IBA}=1.031$ & media $=$ & 1.236 & months $=1$. & Inte & tion $=2.4$ & \\
\hline
\end{tabular}

\section{3- Roots fresh and dry weights}

Data presented in Tables ( $3 \& 4)$ show that IBA at 2000 or $3000 \mathrm{mg} / \mathrm{l}$ increased the fresh and dry weights of Conocarpus erectus roots/cutting, with superiority for IBA at $3000 \mathrm{mg} / \mathrm{l}$ as compared with untreated cuttings in both seasons. The differences between the two used IBA concentration were non- significant in both seasons. Considering the effect of rooting media, data reveal that $\mathrm{M}_{4}$ was the most effective one for giving the heaviest fresh and dry weights of roots/ cutting, followed by using $\mathrm{M}_{3}$ in both seasons. On contrary, $\mathrm{M}_{1}$ medium recorded the lowest values of these parameters in both seasons. As for the effect of planting date, data show that 
planting conocarpus cuttings in May month induced the highest records of roots fresh and dry weights /cuttings, followed in adescending order by July then March months in both seasons .On the reverse, the lowest number of roots / cutting was scored in January and November months in both seasons.

Referring to the interaction effect between IBA, rooting media and planting date, data presented in Table (3) indicate that the combination of May month registered the highest values of this parameter, particularly those treated with IBA at $3000 \mathrm{mg} / \mathrm{l}$ and rooted in $\mathrm{M}_{4}$ medium, whereas the combination of January and November months gave the lowest values in this respect, especially those received no
IBA treatments in both seasons. The rest treatments came in between in both seasons. These results are agreement with those obtained by Bhattacharjee and Thimmapaa (1991) on Pelargonium graveolens who recorded that the heaviest fresh and dry weights of roots/ cutting were obtained from treating with IBA at $2000 \mathrm{mg} / \mathrm{l}$., Eltorky and Shennawy (1993a) revealed that Euphorbia pulcherrima cuttings treated with various concentrations of IBA significantly increased the fresh and dry weights of roots/cutting . Panwar et al., (1994) reported that IBA at 2000 $\mathrm{mg} / \mathrm{l}$, was the best treatment for producing the heaviest fresh and dry weights of Bougairvillea cuttings

Table 3. Effect of IBA, rooting media and planting date as well as their combination on roots fresh weight (g.) of Conocarpus erectus during the two successive seasons of 2010/2011 and 20112012.

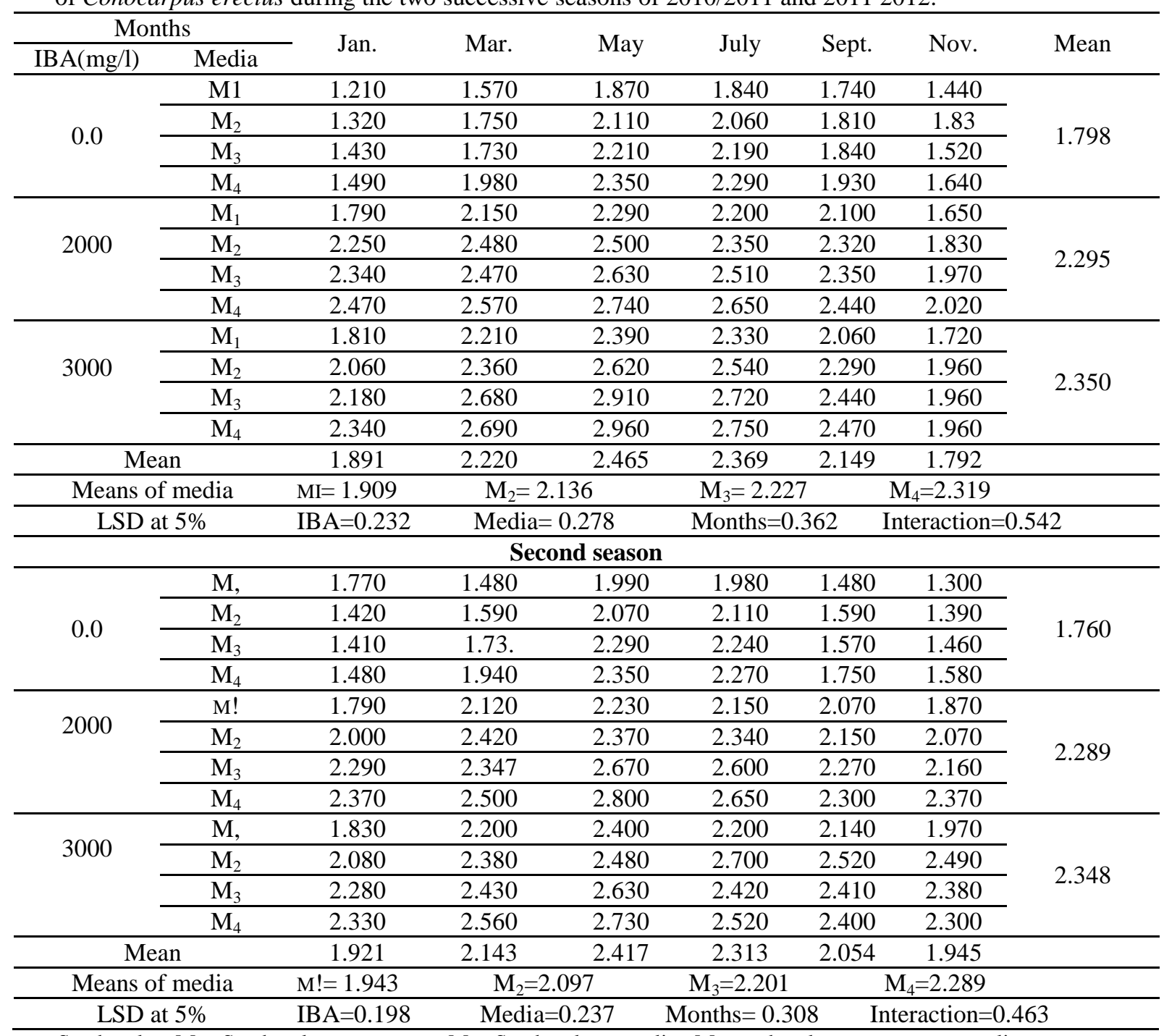

$\mathrm{MI}=$ Sand + clay, $\mathrm{M}_{2}=$ Sand + clay + peatmoss, $\mathrm{M}_{3}=$ Sand + clay + perlite, $\mathrm{M}_{4}=$ and + clay + peatmoss + perlite 
Table 4. Effect of IBA, rooting media and planting date as well as their combination on roots dry weight(g.) of concarpus erectus during the two successive seasons of 2010/2011 and 20112012.

\begin{tabular}{|c|c|c|c|c|c|c|c|c|}
\hline \multicolumn{2}{|c|}{ Months } & Jan & Mar. & \multirow[t]{2}{*}{ May } & \multirow[t]{2}{*}{ July } & \multirow[t]{2}{*}{ Sept. } & \multirow[t]{2}{*}{ Nov. } & \multirow[t]{2}{*}{ Mean } \\
\hline IBA & Media & & & & & & & \\
\hline \multirow{4}{*}{0.0} & $\mathrm{Mi}$ & 0.130 & 0.170 & 0.210 & 0.210 & 0.190 & 0.160 & 0.196 \\
\hline & $\mathrm{M}_{2}$ & 0.140 & 0.190 & 0.240 & 0.230 & 0.200 & 0.170 & \\
\hline & Ms & 0.140 & 0.190 & 0.240 & 0.250 & 0.200 & 0.160 & \\
\hline & $\mathrm{M}_{4}$ & 0.150 & 0.220 & 0.260 & 0.260 & 0.210 & 0.180 & \\
\hline \multirow{4}{*}{2000} & $\mathrm{M}$ & 0.180 & 0.240 & 0.250 & 0.240 & 0.230 & 0.180 & 0.253 \\
\hline & $\mathrm{M}_{2}$ & 0.250 & 0.280 & 0.280 & 0.260 & 0.260 & 0.200 & \\
\hline & Ms & 0.260 & 0.270 & 0.290 & 0.280 & 0.260 & 0.220 & \\
\hline & $\mathrm{M}_{4}$ & 0.270 & 0.280 & 0.300 & 0.290 & 0.270 & 0.220 & \\
\hline \multirow{4}{*}{3000} & $\mathrm{Mi}$ & 0.200 & 0.240 & 0.260 & 0.260 & 0.230 & 0.190 & 0.259 \\
\hline & $\mathrm{M}_{2}$ & 0.230 & 0.260 & 0.290 & 0.280 & 0.250 & 0.220 & \\
\hline & Ms & 0.240 & 0.290 & 0.320 & 0.300 & 0.270 & 0.210 & \\
\hline & $\mathrm{M}_{4}$ & 0.260 & 0.300 & 0.330 & 0.300 & .270 & 0.220 & \\
\hline \multicolumn{2}{|l|}{ Mean } & 0.204 & \multirow{2}{*}{$\frac{0.244}{9}$} & 0.272 & 0.263 & 0.237 & 0.194 & \\
\hline \multicolumn{2}{|c|}{ Means of media } & $\mathrm{M},=0.209$ & & \multirow{2}{*}{$\frac{\mathrm{M}_{2}=0.235}{\mathrm{dia}=0.0218}$} & \multicolumn{2}{|r|}{$\mathrm{M}_{3}=0.244$} & & 0.255 \\
\hline $\mathrm{LS}$ & $5 \%$ & IBA & & & Mont & $s=0.028$ & Interac & 0.042 \\
\hline & & & & cond season & & & & \\
\hline & $\mathrm{Mi}$ & 0.210 & 0.180 & 0.240 & 0.240 & 0.180 & 0.160 & 0.211 \\
\hline م & $\mathrm{M}_{2}$ & 0.170 & 0.190 & 0.250 & 0.250 & 0.190 & 0.170 & \\
\hline 0.0 & Ms & 0.170 & 0.200 & 0.270 & 0.270 & 0.190 & 0.180 & \\
\hline & $\mathrm{M}_{4}$ & 0.180 & 0.230 & 0.280 & 0.270 & 0.210 & 0.190 & \\
\hline & $\mathrm{M} !$ & 0.210 & 0.250 & 0.270 & 0.260 & 0.253 & 0.220 & 0.274 \\
\hline 2000 & $\mathrm{M}_{2}$ & 0.240 & 0.290 & 0.280 & 0.280 & 0.260 & 0.250 & \\
\hline & Ms & 0.270 & 0.280 & 0.320 & 0.310 & 0.270 & 0.260 & \\
\hline & $\mathrm{M}_{4}$ & 0.280 & 0.300 & 0.340 & 0.320 & 0.280 & 0.280 & \\
\hline & $\mathrm{Mi}$ & 0.220 & 0.260 & 0.290 & 0.260 & 0.260 & 0.240 & 0.284 \\
\hline 3000 & $\mathrm{M}_{2}$ & 0.250 & 0.290 & 0.300 & 0.270 & 0.300 & 0.300 & \\
\hline & Ms & 0.270 & 0.290 & 0.320 & 0.290 & 0.290 & 0.280 & \\
\hline & $\mathrm{M}_{4}$ & 0.280 & 0.350 & 0.330 & 0.300 & 0.290 & 0.280 & \\
\hline & & 0.229 & 0.259 & 0.291 & 0.277 & 0.248 & 0.234 & \\
\hline Mean & media & $\mathrm{M} 1$ & & $\mathrm{M}_{2}=0.252$ & & $M_{3}=0.263$ & & 277 \\
\hline LS & $5 \%$ & $\mathrm{IBA}$ & 014 & Media $=0.016$ & Mon & $\mathrm{s}=0.022$ & Interacti & .032 \\
\hline
\end{tabular}

\section{4-On anatomical features}

Data obtained on anatomical features of roots of Conocarpus erectus plants as affected by some treatments of IBA and planting media are shown in Fig(1) The different assigned treatments (M1a-M1c, M2a-M2c , M3a-M3c ,M4a-M4c ) markedly affected the anatomical features of roots of the treated plants. Here, using $\mathrm{M}_{4} \mathrm{~b}$ (sand: clay: perlite: peat moss+ IBA at $2000 \mathrm{mg} / \mathrm{l}$ ) gave the maximum values of root diameter, epidermal layer thickness, number of cortex layers and cortex layers thickness as compared with control. Whereas, the highest value of mean thickness of cortex layers was scored by $\mathrm{M}_{3} \mathrm{a}$ (sand: clay: perlite+ IBA at $2000 \mathrm{mg} / \mathrm{l}$ ), while the thickest vascular cylinder was obtained by $\mathrm{M}_{4} \mathrm{~b}$ ( sand: clay: perlite: peat moss+ IBA at $3000 \mathrm{mg} / \mathrm{l}$ ).Also, the highest number of vascular bundle in vascular cylinder was registered by $\mathrm{M}_{1} \mathrm{~b}$ ( sand: clay + IBA at $2000 \mathrm{mg} / \mathrm{l})$. Moreover, the highest values of thickness of xylem in vascular bundles, number of vessels in xylem bundle and thickness of widest xylem vessel were scored by $\mathrm{M}_{1}$ a (sand: clay), whereas, the highest phloem thickness was gained by $\mathrm{M}_{1} \mathrm{c}$ (sand: clay + IBA at $3000 \mathrm{ppm}$ ). Furthermore, using $\mathrm{M}_{4}$ a (sand: clay: perlite: peat moss) recorded the highest value of paranchymatous pith thickness as compared with the other treatments. 


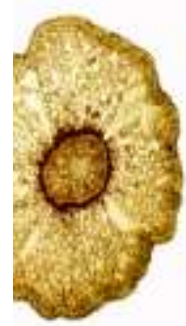

(M1a)

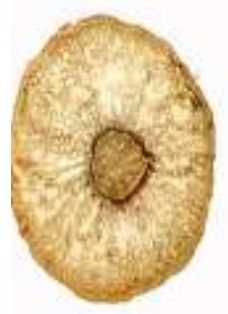

(M2a)

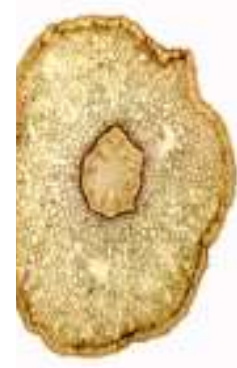

(M3a)

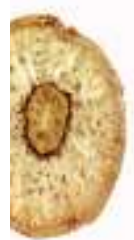

(M4a)

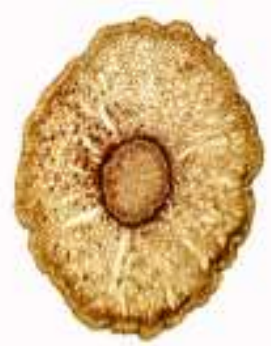

(M1b)

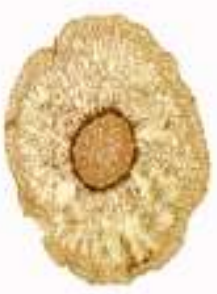

(M2b)

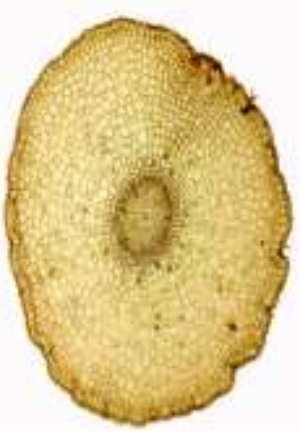

(M3b)

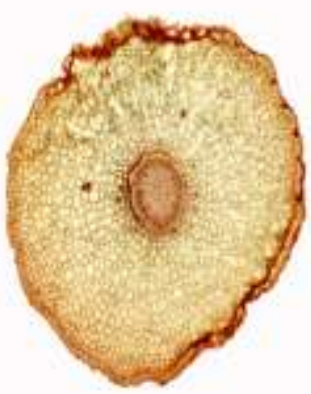

(M4b)

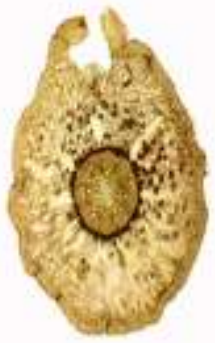

(M1c)

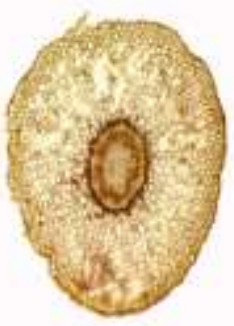

(M2c)

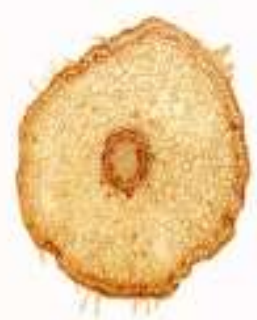

(M3c)

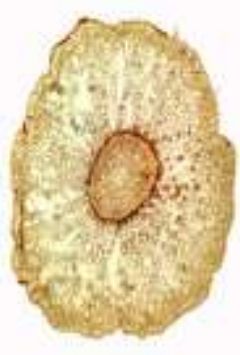

(M4c)

Fig (1): Transvers sections ( $X=40)$ through the root of Conocarbus erectus as affected by different applied treatments. Where: M1a (sand: clay), M1b ( sand: clay + IBA at 2000 mg/L), Mic ( sand: clay + IBA at 3000 mg/L), M2a(sand: clay: peat moss) , M2b(sand: clay: peat moss + IBA at 2000 ppm). M2c( sand: clay : peat moss + IBA at 3000 ppm), M3a ( sand : clay : perlite), M3b ( sand: clay:perlite+ IBA at $2000 \mathrm{mg} / \mathrm{L}) . \mathrm{M3c}$ ( sand : clay : perlite+ IBA at $3000 \mathrm{mg} / \mathrm{L}$ ), M4a( sand : caly: perlite: peat moss) M4b( sand: clay : perlite: peat moss + IBA at $2000 \mathrm{mg} / \mathrm{L}$ ) and M4b( sand : clay: perlite: peat Moss + IBA at $3000 \mathrm{mg} / \mathrm{L}$ ) 


\section{References}

Abo-Hassan, A.A. ;E.F. Zeawail and A.A. Souidan (1994): Effect of different planting substrates and dates on rooting potential of Ficus infectoria cuttings . Annals of Agric. Sci., Moshtohor, 32(2) : 973-986.

Abou-Dahab, A.M.; Y. Shafig; A. Kinany and D.M. Yahya (1975). Effect of seasonal root formation and growth of cutting of different trees and shrubs. Mesopotamia. J. Agric, 10 (112): 3-12.

Bhattacharjee, S.K. and D.K. Thimmappa. (1991). Effects of growth hormone, length of cutting and number of leaves on the regeneration of adventitious roots in Pelargonium graveolens (L) Herit. Annals of Agricultural Science Cairo, 36-2.573-578.

Blithe ,G .(1990): Cutting propagation of Cupressus and Cupressocyparis. Combined Proceeding International Plant Propagation Society, 39 :154-160(Hort .Abst., 61:5105

El-Boraie , E.A.H.(1998): Using cutting and tissue culture technique for propagation of Jasminum sambac and Gardenia jasminoides Ph.D.Thesis , Fac . Agric ., Mansoura Univ., Egypt.

El-Gendy,.N. ; A.M.Hosni and S.E.Saleh (1995a): A Comparative study on the effect of different plant media on rooting of Eunymus japonicus "Auro -Pictus" variegatum .J.A.gric. Sci., Mansoura Univ., 20(4) : 1755 -1759.

Elias, T.S. (1980). The Complete Trees of North America, Field Guide and Natural History. Van Nostrand Reinhold Co., New York, 948pp.

Eltorky, M.G.M. and O.A. El-Sennawy. (1993b): Effect of Indole butyric acid and propagation time on the rooting of Ficus deltoidea and Euphorbia pulcherrema cuttings. Alexandria Journal of Agricultural Research. 38: (1) : 283304.

Gilman, E.F. and D.G. Watson (1993): Conocarpus erectus, buttonwood. Fact Sheet ST- 179. U. S. Forest Service and Southern Group of State Foresters, Gainesville, Fl. 3p.

Howard, R.A. (1989): Flora of the Lesser Antilles, Leeward and Windward Islands. Vol. 5. Arnold Arboretum, Harvard University, Jamaica Plain, MA. 604 pp.

Hartmann H.T; D,E.Kester ;F.T.Davies and R.I.Jr.Geneve (1997): Plant principles and Practies, $6^{\text {th }}$ ed. Prentice Hall ,Engle Wood Cliffs.

Helaly ,A.E.M.(2009). Studies on growth and development of Conocarpus Plant under Dakahlia region condition. Ph.D.Thesis, Fac . Agric ., Mansoura Univ., Egypt.

Istas, W. and I. Meneve (1980): Trails with various root - promoting products. Verbond sieuws voor de Belgische Sierteelt, 23(13): 509-512 (Hort. Abst., 50: 562).
Johanson, D. A. (1940): Plant Microtechnique (5th edition) MC. Grow Hill, Book, Company. New York, London. 213- 236.

Liogier, H.A. (1994): Descriptive Flora of Puerto Rico and adjacent Islands. Vol. 3. editorial de la Universidad de Puerto Rico, Rio Piedras, PR. 461pp.

Lilte, E. L. and F. H. Wadsworlh (1964): Common Trees of Puerto Rico and the Virgin Islands. Agriculture Hand Book 249. U. S. Department of Agriculture, Forest Service, Washington, DC. $548 \mathrm{pp}$.

Nelson, G. (1996): The Shrubs and Woody Vines of Florida. Pineapple Press, Inc., Sarasota, Fl. $391 p p$.

Panwar, R.D.A.K. Gupta; J.R. Sharma and K.P. Rakesh (1994):Effect of growth regulators on rooting in Bouginvillea var. Alok. International Journal of Tropical Agriculture. 12: $\{3-4\}$ : 255261; (c.f. Hort. Abst . 65 \{12\}: 10972.

Pennington, T.D. and J. Sarukhan. (1968): Arbores tropicales de Mexico. Institute Nacional de Investigaciones Forestales, Secretaria de Agricultura y Ganadaria, Mexico D. F., Mexico. 413 pp.

Popovic, R. (1984): Rooting of mature cuttings of Chinese gooseberry, Actinidia chinensis, Arhiv Za Poljoprivredne Nauke, 45(160): 501-506 APRO- RO 1. Strazivacko. Razvojni Institut, Mostar, Yugoslavia (Hort. Abst., 56: 2268). seasonal root formation and growth of cutting of different trees and shrubs . Mesopotamia J.Agric, 10(112) :3-12.

Sass, J. E. (1951): Botanical Microtechnique. Iowa State College Press, Ames, Iowa, 228pp.

Sawwan, J.S. (1993). Propagation of Gypsophila paniculata "Bristol Fairy" by stem cuttings. Advances in HortiSci., 7(3): 103-104. Plant Production Department, Faculty of Agric., Univ. of Jordan, Amman, Jordan. (Hort. Abst, 64:5534).

Shen, X.D. and B.X. Chen (1990). A preliminary experiment on propagation I with green wood cuttings for wolf berry (Lycim barbarum L.) Ningxia Journal of Agro - Forestry Sciences and Technology, 2:18-19. (Hort. Abst, 16:4246).

Singh, S.P. (1993): Effect of auxins and planting time on carbohydrate and nitrogen pracion in semi - hard wood cuttings of Bougainvillea $\mathrm{cv}$. "Thimma" under intermittent mist. Advances in Horti. and Forestry, (3): 157 - 163. (Hort. Abst, 65:8245).

Siraj- Ali , M.S. and A.M.Abou -Dahab (1993): Rooting responses of Schefflera (Brassaia actinophylla) and Ficus benjamina cutting to various media . Annals of Agric . Sci. King 
Faisal Univ ., El. Hassa, Saudi Arabia . (Hort . Abs., 64 :8882).

Snedecor, G.W. and W.G. Cochran (1989): Statistical Methods. $7^{\text {th }}$ Ed. Iowa State Univ. Press. Ames Iowa, USA.

Stevens, W.D.; U.A. Pool and O.K. Montiel. (2001): Flora de Nicaragua. Monographs of
Systematic Botany Vol. 85, No. 1. Missouri Botanical Garden Press, 943pp.

Teklehaimanot,Z. ; Z. ; H.Tomlinson ; T. Lemma and K. Reeves (1996): Vegetative propagation of Parkia biglobosa (Jacq) Benth. An undomesticated fruit tree from West - Africa .Journal of Horticulture Science, 71(2) : 205-215 


\section{تأثير إندول حمض البيوتريك وبيئات التجذير ومواعيد الزراعة على التكاثر الخضرى لشجيرة زلار الخشب}

\section{((Conocarpus erectus L.)}

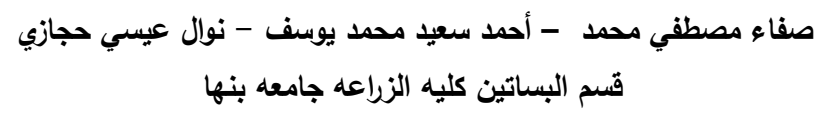

أجريت هذه التجربة خلال عامى 2011/2010 و 2012/2011 فى الصوبة الخشبية بقسم البساتين كلية الزراعة - جامعة بنها -

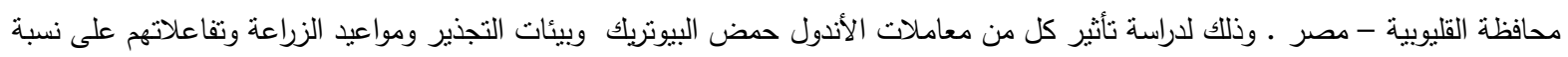
تجذير وعددالجذور والوزن الطانج والجاف للجذور والصفات النتريحية لجذورعقل الكونوكارب لقد أوضحت النتائج الآتي :

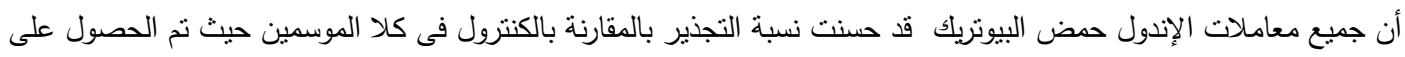

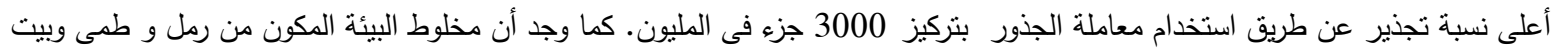

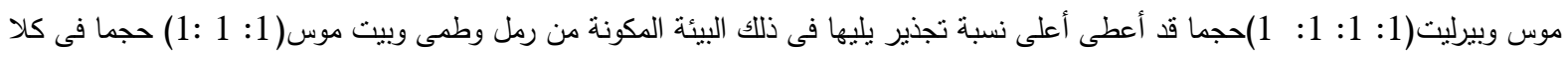

الموسمين - كما وجد أن زراعة عقل النبات فى شهر يوليو قد اعطى أعلى نسبة تجذير يليها فى ذلك شهر مايو وسبتمبر فى كلا الموسمين .

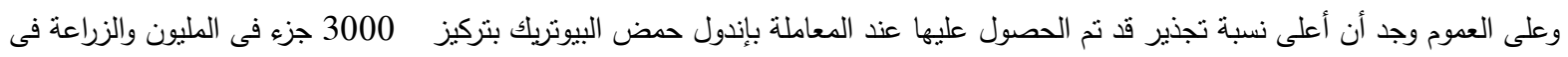

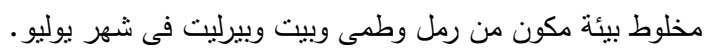
أدى أستخدام اندول بيوتريك أسيد بتركيز 2000 و 3000 جزئ فئ في المليون إلى الحصول على أعلى عدد من الجذور على العقل وكنلك أكبر وزن طازج وجاف للجذور. كذلك أدى استخدام مخلوط الييئة المكون من رمل وطمى بيت وبيرليت إلى الحصول على أعلى عدد من الجذور المتكونة على العقل وكذلك أكبر

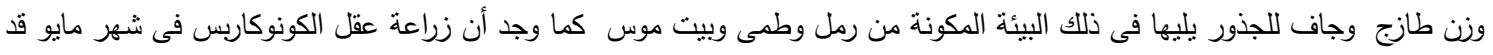

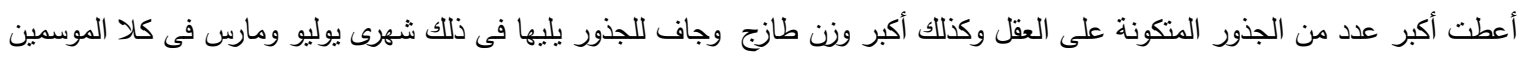

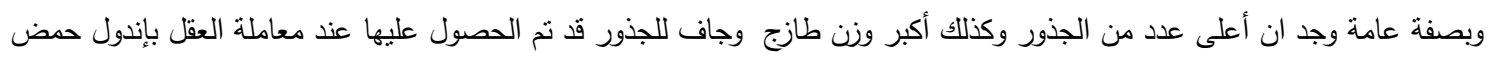

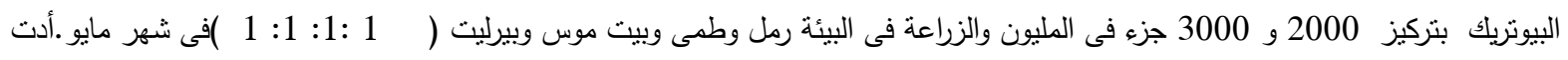

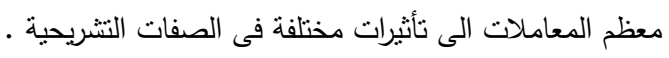

